\title{
Is A SPECIALIST EMPLOYMENT COURT A BETTER FORUM FOR WOMEN?
}

The following three articles are based on three speeches made at one of the seminars in a series of seminars on "Women and Employment" held at Victoria University of Wellington in July 1997.

The topic of the seminar was whether a specialist employment court is a better forum for women.

The following article is based on Maxine Gay's' speech at the seminar. She believes that although the Employment Court may have made gender biased decisions, the Court should nevertheless be retained. She argues that a specialist employment court is important for women because it recognises that the employment contract is one in which the parties have unequal power and it should therefore be treated differently from other contracts. She takes the view that the suggestion by the Business Round Table and Employers' Federation to abolish the Employment Court is part of a wider agenda to casualise the labour force and reduce the rights of employees.

The way this question is posed makes it a difficult one to address. On the one hand the question does not ask which women is the specialist Employment Court a better forum for: working class women, professional women, women lawyers or women who are employers. Although there may be some matters that these different groups of women may have in common regarding the form or style of the Employment Court, the Court is an institution that essentially deals with matters concerning the relationship that women, and men, have to the means of production, distribution and exchange. As such, the answer that one may give to the topic of this seminar does not depend on (as Pam Corkery would say) whether one has a penis or not. Fundamentally, an attitude to the specialist Employment Court depends on one's class position, not one's gender. I will therefore address the question from the point of view of working women, which in most, but not all cases, is similar to the viewpoint of workers as a whole.

* General Secretary, New Zealand Trade Union Federation. 
On the other hand it is impossible to address this topic without reference to time, place or circumstance. While I agree with, and will argue in general terms, the position that a specialist Employment Court is a better forum for working women, we must also note that, at the moment, the Employment Court is created under the Employment Contracts Act 1991(ECA), one of the most pernicious and extreme pieces of industrial legislation in the world. As an institution created by the ECA, asking whether a specialist Employment Court is a better forum for women is the industrial equivalent of asking the question of whether a specialist doctor is a better person to perform female circumcision.

I sometimes worry that we in the trade union movement are developing a starry-eyed view of the current specialist Employment Court, and its judges following some recent judgments from that Court. But let's not have too short a memory. After all, wasn't it the current Chief Judge who in 1989 heavily fined one of our affiliates for alleged contempt of court? That affiliate was the Seafarers Union, which was exercising at the time the internationally recognised right to strike. And wasn't the same Chief Judge also responsible, post ECA, for the infamous Alliance decision which in the immediate aftermath of the ECA cemented in the most extreme aspects of the Act? ${ }^{1}$ It will be recalled that the union in the Alliance case requested the court to condemn various union-busting employer tactics, and the Court declined to do so. It took the Court of Appeal in Eketone to remove some of the harshness of Alliance decision. ${ }^{2}$ It is of little comfort to unions that the Employment Court later repudiated its views. By that time, the damage was done.

A similar comment can be made in relation to partial lockouts. It was this specialist court that endorsed the legality of such lockouts, where workers were held to be legally obliged to accept unilateral pay cuts. Of course the Court two years later reversed itself and condemned such lockouts as equivalent to serfdom. But substantial damage had been done in the meantime. ${ }^{3}$ Just because some recent decisions of the Employment Court have sometimes given some balance to the ECA, we tend to forget that the initial decisions of this same Employment Court were even more extreme than the extremism of the ECA itself.

It is somewhat incongruous that the current more balanced approach of the Employment Court was initially forced on it by the non-specialist Court of Appeal. And even more incongruous that the Court of Appeal, after sending the Employment Court away on the path to rectify its earlier errors, then changed track itself. A change which even caused one of its own members, Justice Thomas, in Ivamy to conclude that: "it is not to be unexpected that

Adams $v$ Alliance Textiles (NZ) Ltd [1992] 1 ERNZ 982.

Eketone v Alliance Textiles (NZ) Ltd [1993] 2 ERNZ 783. 
employers and employees alike may conclude that collective bargaining in the form recognised by the Employment Contracts Act is largely vitiated." ${ }^{4}$

Given that I am not a lawyer, I am probably more at liberty than many here to comment that the u-turns of both the Employment Court and Court of Appeal on these matters seem to depend more on what is happening politically than on points of law. The intervention of the Court of Appeal in the decisions of the Employment Court just happened to coincide with the complaint of the CTU to the ILO regarding the violations of ILO Conventions 87 and 98. Between the ILO upholding the complaint of the CTU and the ILO Direct Contact Mission, the Court of Appeal, then the Employment Court made a number of decisions that moderated the extremes of the ECA and also the extremes of previous decisions of itself and the Employment Court. This action meant the ILO Direct Contact Mission was able to moderate the initial findings of the ILO on the Complaint. However no sooner had the report of the ILO Direct Contact Mission been made, than the Court of Appeal made an abrupt about turn of which Ivamy is a prime example.

And what has the role of the current Employment Court been on matters of specific concern to women workers, namely pay equity and sexual harassment? Wendy Davis has noted that "... the gender bias of decision makers has resulted in decisions which perpetuate male power and privilege, disregard the interests of women, and threaten to undermine the objects of the legislation which make sexual harassment unlawful". ${ }^{5}$ Three years later Caroline Morris, in a report prepared for the Employment Court, noted that "although the poor record documented by Wendy Davis from 1991 to 1993 seems to have improved there is still a distinct trend of undervaluation of the hurt experienced by women in the events leading to a personal grievance claim". She goes on to say: ${ }^{6}$

Women seem to have to suffer more than men in order to receive the same amount of compensation, and when the comments discussing worker distress are analysed, similar amounts are made to men and women who experience differing emotional consequences from their personal grievances. This trend is consistent from 1991-1995 and occurs in both unjustified dismissal actions and sexual harassment cases.

$4 \quad$ NZ Fire Service Commission v Ivamy [1996] 1 ERNZ 85.

5 W Davis Feminist Perspective on Sexual Harassment in Employment Law in New Zealand unpublished LLM Research Paper, Victoria University of Wellington, 1993.

6 CS Morris An Investigation into Gender Bias in the Employment Institutions interim report prepared for the Employment Court, February 1996. 
In her conclusion to "Employment Equity - Unfinished Business" Lorraine Skiffington says: ${ }^{7}$

The specialist employment jurisdiction has failed to deliver employment equity to women employees; ... Rather than breaking down barriers to employment equity the Employment Contracts Act has given employers more scope to exploit women. ... While the specialist employment jurisdiction provides several avenues to address employment inequities, law is fundamentally reactive and incremental, providing limited remedies for the few cases brought before it. ... Importantly it must not be forgotten that employment law is created by male legislators and presided over by a wholly male judiciary ... the Chief Judge has publicly stated that the next three appointments should be women to reflect the gender mix of the workplace.

Skiffington concludes by stating that "until this happens little progress is likely to emanate from employment law." ${ }^{18}$ So, if within the context of the ECA, the Employment Court fails both men and women workers, why do I say at the beginning of this presentation that in general terms that the specialist Employment Court is better for working women?

First, let me take a look at some of the arguments put forward for the abolition of the specialist Employment Court. In August 1996 the Business Round Table and the Employers' Federation jointly published a study by Bernard Robertson on the status and jurisdiction of the New Zealand Employment Court. In a typical piece of BRT/EF tautology, this study begins by claiming that any specialist court "constitutes an interference with the independence of the judiciary." constitutional principles" by depriving private citizens the right of access to the "ordinary courts" and that the role of the Court of Appeal in employment law undermines the arguments for a separate jurisdiction. "The only solution" thunders Bernard Robertson in his executive summary, "which avoids creating disputes and which preserves the principles of free contracting, the independence of the judiciary and the equal application of the law is the abolition of the specialist employment jurisdiction." 10

7 L Skiffington Employment Equity - Unfinished Business, paper presented at "Closing the Gap", a forum on equal pay, Wellington, June 1997, 13.

8 Above $\mathbf{n}$ 7, 14.

$9 \quad$ B Robertson Status and Jurisdiction of the New Zealand Employment Court : A solution (New Zealand Business Round Table and New Zealand Employers Federation, Wellington, 1996) at VII. 
John Timmins, an Auckland barrister writing in the NBR of 20 September 1996 takes issue with Bernard Robertson: ${ }^{11}$

This argument is surely specious. It ignores the existence of a range of specialist courts including, for instance, the Family Court, the Children and Young Person's Court and the Planning Tribunal (now renamed the Environment Court). There is no magic to the status of the High Court; rather it is the constitutional role of the courts generally that is important to the fabric of our society. Certainly the Court of Appeal has had no hesitation in holding that the Employment Court is clearly one of the Queen's courts. To take Mr Robertson's premise to its logical conclusion is to result in absurdities.

Second is my view that the current debate on the need or not for a specialist Employment Court is not really about the Court but is nothing other than a camouflage for the broader and even more sinister agenda of the new right forces. Jane Kelsey exposes part of this in the March 1997 issue of Labour Notes where she states: ${ }^{12}$

Take the assault on the Employment Court. There seems to be two underlying motives. One reflects a general determination to bring the judiciary to heel. Having established a neo-liberal hegemony through most of the bureaucracy, government, media, and private sector, they [the new right forces] have not fully captured the judiciary. Hence the concerted attacks over the past two years directed at Ted Thomas' judicial activism, Dame Silvia Cartwright's condemnation of poverty, the Chief Justice's criticism of unequal access to justice and the Round table's undue influence, alongside broader accusations that the local judiciary are incompetent and economically illiterate.

The second motive is more specific. They are determined to remove any recognition that the labour market is an unlevel playing field, and to subject contracts of employment to the narrowest tenets of ordinary contract law.

The campaign of the unholy trinity of the Business Round Table, Employers' Federation and National First Coalition Government on the Employment Court and its Chief Judge for "judicial activism" must also be seen as part of the wider campaign of these three devils for the abolition of the personal grievance procedures and the introduction of "dismissal at will" employment. That is a system of completely casualised employment. As usual, the forces of the new right have used the BRT as the storm troopers for this old employment philosophy dressed up as a new concept. The Employers' Federation have, as usual, been somewhat more moderate in their demands, seeking a "dismissal at will" system of

11 J Timmins "Courts Have Their Constitutional Rights" National Business Review, Wellington, New Zealand, September 201996.

12 J Kelsey "Mad Max and the Future of the ECA" (Labour Notes, March 1997) 6 and 7. 
employment only for the first 2 years of a worker's employment, and the Coalition Government sits as the referee in this debate, dedicating itself to amend the ECA to bring greater "fairness, flexibility and neutrality".

As part of its storm trooping approach the BRT has once again taken "Goebbels-ism" to a new plane. In one of his initial speeches on this matter, almost two years ago on 22 July 1995, Roger Kerr, Executive Propagandist of the BRT, espoused the need to change the current "dismissal with a cause" system with what he termed with an "employment at will" system. ${ }^{13}$ Notice the big lie technique at work again. Describing a "dismissal at will" system as "employment at will".

He quotes from US Judge Richard Posner stating: ${ }^{14}$

Employment at will is a corollary of freedom of contract, and freedom of contract is a social policy with a host of economic and social justifications ... . Employment at will happens to be the logical terminus on the road that begins with slavery and makes intermediate stops at serfdom, indentured servitude, forced servitude and guild restrictions. That should be a point in its favour.

What a triumph of obfuscation!

This is what happens to the free marketeers who reject the need for any plan or map. They think they have arrived at the terminus of a road that begins with slavery when in fact they have gone in full circle and ended up where they started.

So, is the specialist Employment Court a better forum for women workers?

The answer must be "no" if we compare it to the Arbitration Court of the Industrial Relations Act 1973, or even the Labour Court created by the Labour Relations Act 1987. The Arbitration Court had the ability to make "awards" which ensured the most vulnerable of workers, a majority of whom were women, received wages and conditions well in advance of what the market would have provided. It was the Arbitration Court that was the instrument that ensured the implementation of equal pay in the 1960s and 70s.

But the answer must be a resounding "yes" if we compare it to what the BRT and the Employers' Federation have in mind for us. Their abolition campaign is, as I have shown, part of an attempt to bring the entire judiciary to heel. It is part of an attempt to eliminate any aspect of the human element from employment law and reduce it simply to an aspect of

13 R Kerr "Appeals to the Privy Council" (New Zealand Bar Association Conference, Queenstown, 1995).

14 R Posner "Hegel and Employment at Will: a comment" (1989) Cardozo Law Review, March/April, 1625-36. 
ordinary contract law. It is part of an attempt, in combination with the attempt to abolish personal grievance procedures, to replace the current "dismissal with a cause" system with "dismissal at will" - to completely casualise the New Zealand workforce. It is an attempt to remove the last vestige of employment security that workers in New Zealand have.

If the terminus for worker rights is no rights at all, what does that say about our society as we move into the 21st Century?

Barbara Burton" was the speaker following Maxine Gay. In this article based on her speech, she argues that there is no reason to conclude that the Employment Court is any less favourable a forum for women than any other forum. She highlights some of the cases decided by the Employment Court which have had positive outcomes for women and also suggests that low level meditation might be the best way to resolve employee disputes.

Asking "Is the Employment Court a better forum for women?", raises a second, very obvious, question: better than what? Because comparing the Employment Court with the High Court, the answer is, we do not know. Personal grievance outcomes highlight the difficulty.

An initial personal grievance procedure came into being in 1970. Before then the specialist industrial court (the Court of Arbitration) had concerned itself largely with the making of awards, and with the interpretation of awards and industrial agreements. The procedure developed over time and its availability was extended by the Employment Contracts Act (ECA) to all employees. This change occurred not long after the High Court, in common law employment termination cases, found itself able to award compensation beyond moneys owing on termination under the terms of the employment contract. Previously, only those employed under awards or agreements, or employees outside the award/agreement system who belonged to the union with coverage of their kind of work (the latter added by the 1987 Labour Relations Act), could make use of the statutory procedure and so avail themselves of the statutory remedies. All other employees were restricted to High Court actions where the Addis $v$ Gramophone case ${ }^{15}$ had, since 1909, very much limited what the Court could award. Addis concerned a wrongful dismissal carried out in a harsh and humiliating way. It held that damages for non-pecuniary loss were generally not recoverable where the breach of contract had caused vexation, annoyance, or distress. That view persisted for many years thereafter.

- Legal Advisor of the New Zealand Employers' Federation. 
Only in 1990, in Whelan $v$ Waitaki Meats $L t d,{ }^{16}$ did the High Court turn its back upon the Addis rule, finding that (with the advent of personal grievance provisions) that case resulted in: ${ }^{17}$

... the quite illogical distinction that damages or their equivalent could be recovered by persons who were entitled to invoke the statutory provisions relating to employment but not whose employment was such as to preclude them from the benefit of the statutory principles.

This was a situation which the Court considered possible, but undesirable. In the event, the ECA, coming hard on the heels of Whelan, removed the need for any further judicial reinterpretation.

So how have women fared under the specialist jurisdiction? Consider, for example, two of the cases cited in Whelan in support of the High Court's determination to produce a fair result for the plaintiff. Both were 1985 judgments of the Court of Appeal, the one an appeal from a decision of the Arbitration Court (under the Industrial Relations Act 1973), the other an appeal from a High Court judicial review.

The first case, Auckland Shop Employees' Union $v$ Woolworths (NZ) $L t d^{18}$, saw the Arbitration Court uphold the employer's action, following allegations of possible dishonesty, in setting up an inquiry which had led to the resignation of the employee in question, a young, female, check-out counter operator. Although made under stress, the employee's decision was held to have been her own; it had not constituted a constructive dismissal.

In the Court of Appeal, however, it was suggested - although not finally determined that there ought to be a relationship of confidence and trust implied as a normal incident of the relationship of employer and employee. This would be the corollary of the employee's duty of fidelity. But there must at least be an implied term or duty binding an employer to carry out any inquiry into possible dishonesty in a fair and reasonable manner. This duty might: ${ }^{19}$

... be seen as part of a wider duty [as above], or as an application of natural justice to contemporary industrial relations, or perhaps most naturally as combining both ideas.

Setting up an inquiry was not, as the Arbitration Court could be taken to have suggested, the end of the issue of constructive dismissal. The case was referred back for that

$16 \quad$ [1991] 2 NZLR 74.

17 Above n 16, 88-89.

18 [1985] 2 NZLR 372.

14 Above n 18, 376. 
Court to consider, or reconsider, whether in its conduct of the inquiry the employer, through its officers, had acted in a fair and reasonable manner towards the worker.

The Woolworths case was heard early in 1985, Marlborough Harbour Board $v$ Goulden $^{20}$ towards the end of that year. In Goulden, the Harbour Board sought unsuccessfully to have set aside a decision of the High Court that it reconsider the dismissal of its general manager. Citing the recent Woolworths decision the Court of Appeal pointed out that there: ${ }^{21}$

... this Court accepted that in the sphere governed by the Industrial Relations Act 1973 the relationship of confidence and trust that ought to exist between employer and employee imports duties on both sides, including a duty on the part of the employer, if carrying out an inquiry preceding a resignation or dismissal ... to do so in a fair and reasonable manner. Perhaps a similar implication might quite readily be found in private contracts of employment not subject to the 1973 Act. Fair and reasonable treatment is so generally expected of any employer that the law may come to recognise it as an ordinary obligation in a contract of service.

The general manager fared better in the High Court than the checkout counter operator in the Arbitration Court but, in the hands of the Court of Appeal, both cases paved the way for a more sympathetic hearing for all employees. What is more, the Woolworths decision gives the lie to the notion that a specialist court is necessarily a better forum for women. Without the Court of Appeal's willingness to read in what amounted to a natural justice requirement, the employee's resignation, although reluctantly given, would have stood.

And in Goulden are the first indications that fair and reasonable employee treatment should be an element of all employment contracts, with or without a statutory personal grievance procedure. The consequence was a High Court emboldened to find for Mr Whelan and a gradual closing of what, until then, had been an ever-widening gap between statutory and common law entitlements. Had the ECA not brought all employment contracts under its aegis, the Whelan decision would doubtless have seen more employees, male and female, looking to the High Court for redress. Previously, the unavailability of compensatory damages would have deterred many a potential litigant.

Particular decisions aside, however, the notion that a specialist employment court is a better forum for women is inherently flawed, suggesting as it does that "female" cases should in some way be judged differently from "male" cases. The law may not, in practice, be as

[1985] 2 NZLR 378.

Above $\mathrm{n} 20,383$. The resolution to terminate the general manager's appointment had been made in terms of the Harbours Act 1950. It therefore constituted the exercise of a statutory power of decision "falling within the letter and spirit of the Judicature Amendment Act 1972", providing the basis for an application for review. 
impartial as strict theory might require, but its application should not vary with the sex of the employee.

The much maligned decision in the Clerical Workers Union's equal pay claim ${ }^{22}$ is a case in point. The Arbitration Court there found that it had no jurisdiction to hear and determine questions submitted under the Equal Pay Act 1972 because the negotiated award contained no element of differentiation between rates payable to male employees and those payable to female employees. The award complied with the Act's equal pay definition:

[Equal pay] means a rate of remuneration for work in which rate there is no element of differentiation between male and female employees based on the sex of the employees, and consequently the choice of the Equal Pay Act as a vehicle for remedying perceived problems was an error of law. Problems had arisen because awards in male-dominated employment areas (such as the Building Trades Award) provided different and higher pay rates from those in the Clerical Award. Bound by the Act's definition of equal pay, the Court found itself unable to point the way to the establishment of new pay rates beyond the rates already negotiated.

More recently, the Employment Court, in the first homecare workers' case ${ }^{23}$ (Cashman) found that homecare worker plaintiffs did not come within the ECA's section 2 definition of homeworker and so could not be classified as employees ${ }^{24}$. Homecare workers had always been employed as independent contractors under contracts for services and as such were able to manage their own affairs, refuse assignments, and so on. But they had no statutory employee entitlements - to holiday pay, parental leave, the protection of the ECA's personal grievance provisions and the like.

It was for just those kind of reasons that the Court of Appeal found itself convinced by the argument that, whatever the form of their contract, homecare workers were effectively homeworkers, being in the kind of vulnerable position contemplated by those responsible for including "homeworker" in the ECA's definition of "employee". They were, the Court said, "... very much the type of worker who needs the protection of the Act by being deemed an employee notwithstanding a contractual description of "independent contractor". ${ }^{25}$ It

NZ Clerical Administrative etc IAOW v Farmers Trading Co Ltd [1986] ACJ 203.

Cashman $v$ Central Regional Health Authority [1996] 1 ERNZ 1

"Homeworker means a person who is engaged, employed, or contracted by any other person (in the course of that other personís trade or business) to do work for that other person in a dwellinghouse (not being work on that dwellinghouse or fixtures, fittings, or furniture in it); and includes a person who is in substance so engaged, employed or contracted notwithstanding that the form of the contract between the parties is technically that of vendor and purchaser."

Cashman v Central Regional Health Authority [1997] 1 NZLR 7, 13. 
would be surprising if, at least as an immediate response, the women in Cashman did not think themselves better served by the Court of Appeal than by the specialist employment court.

Then there is the case of Smith $v$ Radio $i \mathrm{Ltd}$. $^{26}$ Here a full Employment Court upheld the legitimacy of the plaintiff's second fixed term contract, refusing to find either that she had been unjustifiably dismissed or that there had been a contract breach. Although the radio broadcaster plaintiff had expressed a wish to be re-engaged for a third term, what the Court described as a "parting of the ways" came when she refused to accept a reduction in salary and reduced employment terms. The Court found the defendant able to rely on the contract term which stated, effectively, that the contract was for a limited and defined period at the end of which it would cease or expire.

The Smith decision produced a result rather different from that in two later fixed term contract cases, both involving male employees and both subsequently reversed by the Court of Appeal. In the first, Haddon, ${ }^{27}$ a university lecturer employed on a fixed term lectureship had failed to gain appointment to a newly-created position in his Department. The full Employment Court rejected his claim of unjustified dismissal but, nevertheless, concluded that a single judge should consider whether he had an unjustifiable disadvantage grievance because of his treatment in the course of the appointments process. Compare this with the outcome of a 1991 case ${ }^{28}$ where a female Teachers' College lecturer employed under a fixed term contract was interviewed for, but not appointed to, a new position. The finding: she had "clearly entered into a fixed term contract which terminated at the conclusion of its term".

As for Haddon, on appeal, the Court of Appeal ${ }^{29}$ pointed out that the situation there was not one where the employment relationship contemplated promotion to a new position, with a corresponding expectation of fair treatment. The limited term appointment would expire in any event, while chances of securing a new appointment depended on prevailing in the appointments process against all other applicants. Consequently the Court was not able to inquire into the functioning of the Appointments Committee by way of a disadvantage grievance.

[1995] 1 ERNZ, 281 - the case also involved a claim at common law for breach of contract.

Haddon $v$ Victoria University of Wellington [1995] 1 ERNZ 375.

Association of Staff in Tertiary Education $v$ Christchurch College of Education [1991] 3 ERNZ 796.

Victoria University of Wellington $v$ Haddon Unreported, 24 April 1996, Court of Appeal, CA 134/95. 
The other (male employee) fixed term contracts case, Hagg $v$ Auckland College of Education, ${ }^{30}$ is notable for taking two appeals to the Court of Appeal to establish that $\mathrm{Mr}$ Hagg had neither been disadvantaged in his employment nor unjustifiably dismissed. In both instances there was a finding for Mr Hagg in the Employment Court and against him in the Court of Appeal. In the Employment Court, the termination of a second fixed term contract had been held to constitute an unjustifiable dismissal. ${ }^{31}$ The Court of Appeal, for its part, had this to say: ${ }^{32}$

Dismissal is the act of the employer in terminating the contract. Merely to allow a limited term contract to come to an end by effluxion of time is not a dismissal.

A final example, and one which also went to the Court of Appeal, is Lang $v$ Eagle Airways $L t d .^{33}$ This case concerned a female airline pilot whose employment was terminated after health problems led to greatly reduced flying times and ultimately to a Civil Aviation Authority Air Transport Division requirement that she fly only if accompanied by a safety pilot. As the planes she flew were two-pilot planes, with the co-pilot having his or her own specific duties to perform, the company was unable to comply fully with this requirement, and the Air Transport Division would not reword it. A Tribunal hearing produced a finding for the grievant, but both the Employment Court and the Court of Appeal considered the company entitled to terminate the employment.

While I can understand the temptation to believe that women do better with a specialist Employment Court, this contention is not something which the cases appear to support. Nor, from my, admittedly limited experience as an employer appointee to the Labour Court, was there at that time, any tendency, expressly or impliedly, to find for a female employee where one might not have found for a male employee. To have done so would, in my view, have constituted paternalism of the worst sort. Moreover, a brief examination of recent cases suggests that males and females succeed and fail in fairly equal numbers - not, admittedly, a scientific conclusion.

It is of passing interest that when, in 1970, an amendment to the then Industrial Conciliation and Arbitration Act (the amendment referred to "wrongful" dismissal, the common law term; "unjustified"dismissal came with the 1973 Industrial Relations Act) first introduced a personal grievance procedure, it referred to the employee as "him" The primary

Hagg $v$ Auckland College of Education [1995] 2 ERNZ 239.

Hagg $v$ Auckland College of Education Unreported, 5 September 1996, Employment Court, Auckland Registry, AEC 53/96.

Principal of Auckland College of Education v Hagg [1997] 2 NZLR 537, 554.

[1996] 1 ERNZ 574. 
intention was that employment disputes, then the source of considerable industrial unrest, should be settled as expeditiously as possible. In 1991, however, when the ECA bestowed the benefits of the statutory personal grievance (as well as the statutory disputes) procedure on all employees - allowing them to act either on their own account or through a chosen representative - some of the first cases were taken by women.

In the Superstrike case, ${ }^{34}$ the Labour Court disallowed a proposed unilateral variation of the employee's terms and conditions of employment which would have required her to work other than at weekends. It pointed out that section 19(4) of the ECA entitled the applicant, on the facts of the case, to import into her individual contract of employment the same terms and conditions which she was enjoying before the statute came into force. ${ }^{35}$

And in the Telecom case $^{36}$ it was another female employee whose complaint led the Court of Appeal to conclude that notwithstanding the company's agreement to pay a penal rate for work on a statutory holiday, any employee who worked on such a day, and for whom that day would otherwise have been an ordinary working day, was entitled as well to a day off in lieu.

So, no, I do not think that a specialist Employment Court is a better forum for women, nor do I think the evidence supports that contention. But what I do think is that all employees might be better served by confining disputes resolution to low-level mediation, using either a statutory procedure, or allowing the parties to agree to a procedure of their own. Appeals, if provided for, could be to the High Court where, on the evidence of recent appeals to the Court of Appeal, women would be quite as likely to succeed as their male counterparts.

Implicit in the suggestion that women do better with a specialist Employment Court is the notion that women can't quite cut the mustard in the real world. That is a notion which, personally speaking, I find rather offensive.

34 Grant $v$ Superstrike Bowling Centres Ltd, [1992] 1 ERNZ 727. The case was heard in July 1991 by the Labour Court exercising the powers of the Employment Tribunal pursuant to sections 186 and 187 of the ECA. Special provisions establishing the Tribunal did not come into force until 19 August 1991.

35 Above $n$ 34, 734.

36 Labour Inspector v Telecom Networks and Operations Ltd [1993] 1 ERNZ 492. 
The preceding two speakers were followed by a commentary by Lianne Dalziel. The article based on this commentary is below. Lianne Dalziel makes some interesting comments on both speeches. She argues that a specialist employment court is a preferable option for women and points out that the employment contract is distinguishable from an ordinary commercial contract in that it involves a human relationship in which power and control can be exerted.

I regard the Employment Contracts Act as one that has worked to the detriment of women, particularly those who are in the low-paid sector that I used to represent. I have seen conditions of employment that were won through action or arbitration or both, lost by the imposition of the individual contract or the 'take-it-or-leave-it' attacks on the collective contract. Minimum statutory provisions have often become the new maximums, for example, 5 days domestic leave to cover sick leave and bereavement leave. I have seen the stresses and strains increase on low income families, many of whom have increased their working hours or taken on extra jobs, to make up for the shortfall in income experienced since the ECA came into effect. Union membership has fallen over the past six years, not so much a result of the organising ability of the union organisers, but through fear, apathy and ignorance.

I have never worked under the ECA, only the Labour Relations Act, and therefore my personal experience is only that of the Mediation Service and the Labour Court. Therefore, when I read "is a specialist Employment Court a better forum for women?", my immediate answer was yes. I would not look at the Employment Court in isolation from the whole structure, which today includes the Employment Tribunal. There are many cases resolved at that level, without the need to refer to the Court.

I felt that this was missing from Barbara Burton's contribution. But perhaps that was simply the way the question was worded, and she did in her concluding remarks call for low-level mediation. I also detected a degree of defensiveness in her contribution, in relation to the whole question of women. It is as if there ought to be no question that men and women are treated equally under the law. We wouldn't be having an extensive Law Commission project on that very topic if such an assumption could not be challenged.

Access to legal remedies is an important issue, and I know that there are many cases which union officials take through the system that would never have been taken had there been the requirement to act individually and hire a lawyer to take a case through the civil courts. Homecare workers are a case in point. They would never have made it to the Court of Appeal without the support of the union.

- MP, Labour Spokesperson on Health. 
However, I felt Barbara Burton did raise some interesting points about the Court of Appeal's instincts in relation to the inherent lack of natural justice in the ECA, with its assumptions of equality of bargaining position. It is true that the Court of Appeal has gone where the Employment Court felt that it could not, but I think it important to remember that many of these concepts are having their first test in the market environment of the Act. It is therefore not surprising that the Court of Appeal has made some significant pronouncements in what can be seen as fairly early days in the operation of the Act.

Obviously I have a preference for a specialist court in the field of employment. Why? Because employment isn't just a contract; it is a relationship; a human relationship. It is one where power and control can be exercised.

A specialist court can look at the relationship rather than the strict terms of a contract, in the same way as the Family Court deals with relationship issues, rather than the civil courts. In fact the analogy is a good one - marriage and employment are both relationships, to which the law attaches certain rights and responsibilities. There should be an emphasis in both areas on reconciliation through mediation and counselling, except perhaps when there has been a fundamental breach.

I appreciated Barbara Burton's consideration of the history of the current personal grievance provisions, but there is a point that I would further emphasise. The traditional response of workers to the unfair or coercive use of employer power was collective. The catch-phrase "an injury to one is an injury to all" meant that the unfair treatment or dismissal of a workmate or colleague tended to provoke an industrial response. The right to take industrial action in support of a workmate, however, was traded off for the statutory grievance provisions. This was of much greater benefit to those in isolated positions in scattered workplaces. Those sorts of jobs are dominated by women, and, therefore, women did gain considerably from the development of personal grievance provisions and an accessible legal jurisdiction.

One of the concerns that I have is that fees for lodging cases with the Tribunal and the Court are due to double on the 1st of August this year, and although they might appear small to those of us on reasonably good incomes, I am concerned that they may create barriers to access, particularly when there is no income after a dismissal. However, as I have indicated, I would be deeply concerned at the loss of the specialist jurisdiction, because I believe many workers, particularly the low paid, would not pursue legitimate claims for fear of the cost.

With regard to the comments about equal pay, I would simply highlight that the gap between men and women remains at between $80-81 \%$, and as I said in my maiden speech, the day the market delivers equal pay for work of equal value, is the day we can all sit around and watch pigs flying overhead. 
I recall that Mr Birch was desperate to repeal Helen Clark's Employment Equity legislation before Christmas in 1990, because nurses were about to have their salaries compared with police salaries. Of course, not all the difference would have been gender based, but a proportion of it would have been. And the identification of the gender gap was far too political for Mr Birch and his colleagues.

Maxine Gay has adopted the position that an attitude to a specialised employment court was more of a class issue than a gender issue. I accept many of the points that are made, but I keep coming back to the reality, that women are over-represented in the low paid jobs, where the minimum wage and statutory protections are all that remain since the demise of the Award system. The promised flexibility to negotiate directly with your employer has done little or nothing for this group.

Maxine Gay made comments about the language that is used ("employment at will" for "dismissal at will"). I too have expressed my concerns about the capture of the language like labour market flexibility, freedom of choice - it puts people arguing against them on the back foot. You should be aware that I looked "flexible" up in the dictionary. It means "pliant and docile" - exactly the sort of workforce that is being sought.

I also share in Maxine Gay's view that the Employment Court may not be the best example of a specialist employment court, but I do believe the arguments to retain one, far outweigh the arguments against.

However, I congratulate both contributors to tonight's forum for the work they have put into their presentations. They each represented their points of view strongly, and they represent an important element of the public debate that will surround the review. Unfortunately, if Maxine is right then the decision is already made. I hope that if sufficient voices are added to the debate that that will not be the case. 